Izvorni znanstveni članak Primljen: 29. travnja 2021. Prihvaćen: 20. rujna 2021.

doc. dr. sc. Dubravka Kuščević

Filozofski fakultet Sveučilišta u Splitu

Poljička cesta 35, 21000 Split

kuscevic@ffst.hr

http://orcid.org/0000-0002-4572-9933

\title{
STAVOVI I RAZMIŠLJANJA UČENIKA O PRIRODNOJ I KULTURNOJ BAŠTINI
}

Sažetak: Kulturna i prirodna baština bogatstvo je naroda kojemu pripada te jedan od ključnih elemenata za stvaranje nacionalnoga kulturnog identiteta $i$ afirmacije u procesu globalizacije društva. Cilj istraživanja bio je ispitati stavove, informiranost $i$ razmišljanja učenika osnovnih i srednjih škola o prirodnoj $i$ kulturnoj baštini. U istraživanju je sudjelovalo 322 ispitanika iz osnovnih i srednjih škola Splitsko-dalmatinske, Šibensko-kninske i Zagrebačke županije. Analiza rezultata ukazuje na to da učenici srednjih škola iskazuju bolje poznavanje kulturne i prirodne baštine zavičaja te viši stupanj zainteresiranosti za upoznavanje tih sadržaja nego učenici završnih razreda osnovne škole. Također, više prepoznaju vrijednost pridavanja značaja tim temama u okviru rada odgojno-obrazovnih ustanova i u okviru različitih nastavnih predmeta. Usto, srednjoškolci izražavaju veću svijest o važnosti očuvanja kulturne baštine te njezine povezanosti s razvojem gospodarstva i očuvanjem nacionalnog identiteta nego učenici osnovnih škola. Nije bilo razlika među učenicima po pitanju utjecaja kulturne baštine na poticanje njihove kreativnosti, no pokazalo se da je češće posjećivanje arheoloških institucija povezano s višim interesom za sadržaje baštine.

Ključne riječi: identitet, poznavanje baštine, zaštita.

\section{UVOD}

Hrvatski prostor bogat je raznolikim kulturnim nasljeđem. U multikulturalnom svijetu kulturno naslijeđe - prirodna i kulturna baština može biti temelj napretka društva. O stavovima mladih generacija te njihovu odnosu i odgovornosti prema kulturnom nasljeđu koje stječu edukacijom ovisi održiva budućnost naroda. 
Pojam kulturne i prirodne baštine multidimenzionalan je te postoje različite definicije koje ga pokušavaju osvijetliti, a problematika pojma pokušava se razjasniti u mnogim područjima znanstvenih disciplina kao što su kulturna antropologija, filozofija, politologija, sociologija i pedagogija. Jedna od definicija baštine o baštini govori sljedeće: „Kulturnu baštinu čine: kulturni krajolik, povijesne cjeline, pojedinačne građevine i pokretna baština. Njezine vrijednosti prepoznajemo kao: starosne, povijesne, kulturne i emotivne. Autentičnost povijesnih struktura jedna je od temeljnih vrijednosti“" (Maroević, 2001, str. 235). Uz kulturnu baštinu Hrvatska se ponosi i prirodnom baštinom. Ističe se da „baština, osim kulturne baštine, uključuje i prirodnu baštinu koja prema Konvenciji za zaštitu svjetske kulturne i prirodne baštine označava prirodne odlike koje se sastoje od bioloških, geoloških i fizičko-geografskih formacija koje su od izuzetne svjetske vrijednosti s gledišta znanosti, zaštite i očuvanja prirode i prirodnih ljepota“ (Kostović, 2015, str. 445).

U znanstvenoj literaturi uz razmišljanja o kulturnoj baštini uvodi se pojam kulturnog dobra te navodi: „Kulturna su dobra pokretne i nepokretne stvari od umjetničkoga, povijesnoga, paleontološkoga, arheološkoga, antropološkog i znanstvenog značenja; arheološka nalazišta i arheološke zone, krajolici i njihovi dijelovi koji svjedoče o čovjekovoj prisutnosti u prostoru, a imaju umjetničku, povijesnu i antropološku vrijednost; nematerijalni oblici i pojave čovjekova duhovnog stvaralaštva u prošlosti, kao i dokumentacija i bibliografska baština i zgrade, odnosno prostori u kojima se trajno čuvaju ili izlažu kulturna dobra i dokumentacija o njima“" (Boljanović, 2011, str. 54). Kulturno nasljeđe (baština) i kulturno dobro, iako imaju slična značenja za predmet koji opisuju, kao pojmovi nisu isti. Razlika između kulturnog nasljeđa (baštine) i kulturnog dobra je $\mathrm{u}$ tome što se kulturno nasljeđe odnosi na društvenu zajednicu i pridonosi općem dobru, time pojam ima šire značenje. Kulturno dobro pojmovno određuje materijalne i nematerijalne oblike imovine kao što su zgrade, slike, spisi koji utječu na identitet, razumijevanje i poštovanje kulture koja je proizvela kulturno dobro (Vuković, 2011).

Dakle baština se vezuje uz prirodna i kulturna, duhovna i materijalna dobra u širokom kontekstu pridavanja značenja samom pojmu. Baština može biti lokalna, nacionalna, a ponekad zbog svoga posebnoga značenja može predstavljati i baštinu cjelokupnog čovječanstva. (Šošić, 2014) ističe kako je pojam baštine slojevit i raznolik te je njegovo definiranje povezano s teškoćama. Zato se zaključuje kako je pojam baštine dinamičan i kako ga možemo uvijek razmatrati u svjetlu novih značenja i vrijednosti.

U znanstvenoj literaturi o kulturnoj baštini govori se s obzirom na različite kontekste o različitim vidovima baštine kao što su društveni ili ekonomski, no isto tako o baštini se govori kao o važnom pokretaču društvenog razvoja te o mogućnostima baštine u obrazovanju i kreativnom razvoju pojedinca u doticaju s baštinom. Mnogi autori ističu važnost baštine kao kulturnog zajedničkog 
dobra lokalne zajednice, društva i čovječanstva te ističu važnost zaštite kulturnog nasljeđa (Boljanović, 2011; Cifrić, 2010; Cifrić i Trako Poljak, 2014; Maroević, 2001; Živković, 1996), dok drugi autori naglasak stavljaju na razvoj identiteta putem baštinskih vrijednosti. (Fulcher i Scott, 2011; Georgievski i Žoglev, 2014; Mendras, 2004; Reeves i Plets 2016; Vuković, 2011) baštinu povezuju s kolektivnim pamćenjem zajednice koja ima presudnu važnost za očuvanje zajednice.

O kulturnoj baštini u području odgoja i obrazovanja sve više se govori i piše, a često se u odgoju i obrazovanju ističe važnost očuvanja kulturne baštine u poticanju shvaćanja vrijednosti održivog razvoja. U odgojno-obrazovnoj praksi baština u nastavi ima svrhu promicati obrazovanje za održivi razvoj (Čukelj, 2009). Iskustva stečena u djetinjstvu imaju važnu ulogu u oblikovanju stavova, vrijednosti i načina ponašanja pojedinca prema okruženju (Kostović Vranješ i Jukić, 2011), zato je važno učenike zainteresirati za okruženje tijekom njihova odgoja i obrazovanja. Pri tome važno se osvrnuti na ono vrijedno što u tom okruženju postoji, a što zapravo predstavlja prirodnu i kulturnu baštinu naroda. U tom duhu ističe se: ,da bi očuvanje nacionalne baštine bilo djelotvorno, neophodno je započeti s odgojem i obrazovanjem za održivi razvoj već od najranije dobi i kontinuirano ga provoditi na svim razinama formalnog obrazovanja“ (Kostović, 2015, str. 439). Prirodna i kulturna baština u odgoju i obrazovanju posebno je zanimljiva i u području likovne pedagogije, gdje neki autori u kontaktu učenika s baštinom naglasak stavljaju na razvoj kreativnih potencijala učenika (Brajčić i Kuščević, 2008; Kuščević, 2007; Kuščević, 2015; Pivac, 2016).

Kulturni identitet Hrvatske, zbog specifične povijesti i zemljopisa, karakterizira izrazita regionalna raznolikost prirodne i kulturne baštine s različitim slojevima prirodnog i kulturnog nasljeđa, zato je u sustavima formalnog obrazovanja nužno podučavati o baštini interdisciplinarno, povezujući različite nastavne predmete. Na takav način učenici grade sliku o prirodnoj i kulturnoj baštini Hrvatske koja je važna za gospodarski napredak, razvoj identiteta učenika te razvijanje svijesti o važnosti očuvanja baštine kao važnog resursa za budućnost. U znanstvenoj literaturi danas govori se i o konceptu baštinske pismenosti (Babić i sur., 2019). Baštinsku pismenost vidimo kao važnu vrstu pismenosti potrebnu u 21. stoljeću u obrazovanju djece i mladih, stoga smo proveli ovo istraživanje kako bismo saznali stavove i razmišljanja učenika o navedenoj temi.

Cilj istraživanja bio je ispitati stavove i razmišljanja učenika o kulturnoj baštini, odnosno ovim istraživanjem želimo istražiti poznaju li učenici baštinu, shvaćaju li vrijednost baštine u gospodarskom razvoju i razvoju identiteta te pokazuju li interes za upoznavanjem baštinskih sadržaja. Također, ovim radom želimo saznati kako obrazovanje utječe na znanja i stavove o baštini, poznaju li učenici važnost očuvanja baštine i utječe li baština na učenički kreativni razvoj. 
U ovom istraživanju postavili smo sljedeća istraživačka pitanja:

- Poznaju li učenici baštinu zavičaja?

- Pokazuju li interes i motiviranost za upoznavanje sadržaja kulturne baštine?

- Pridaje li se u okviru odgojno-obrazovnog rada dovoljno pozornosti sadržajima kulturne baštine i na kojim nastavnim predmetima te shvaćaju li učenici da je to važno?

- Jesu li učenici svjesni važnosti očuvanja kulturne baštine?

- Jesu li svjesni povezanosti razvoja gospodarstva s očuvanjem i prezentacijom kulturne baštine?

- Jesu li učenici svjesni važnosti kulturne baštine u očuvanju identiteta naroda?

- Utječe li doticaj s kulturnom baštinom na poticanje kreativnosti učenika?

- Utječe li posjećivanje muzeja, galerija i arheoloških lokaliteta na interes učenika prema poznavanju i doživljavanju baštine?

\section{METODOLOGIJA}

\section{OPIS UZORKA}

Istraživanje je provedeno na ukupno 322 učenica i učenika završnih razreda osnovnih i srednjih škola. U istraživanju je sudjelovalo 49 \% učenica i učenika iz osnovnih škola, a učenika i učenica srednje škole bilo je $51 \%$. Postotak zastupljenosti pojedinog razreda vidljiv je na grafičkom prikazu 1, a postotak zastupljenosti prema spolu na grafičkom prikazu 2.

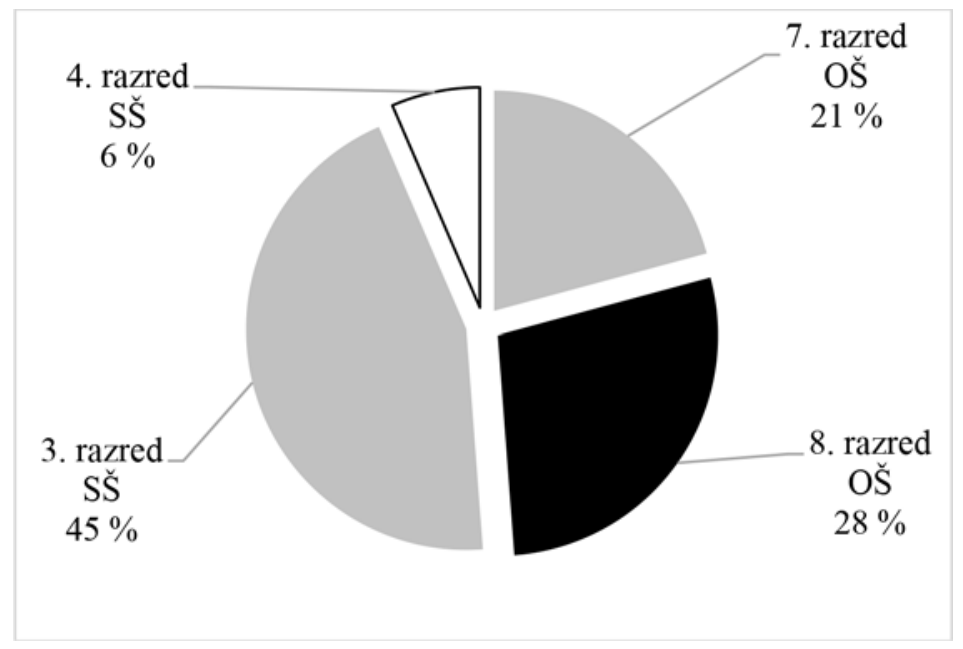

Grafikon 1. Postotak ispitanika prema razredima 


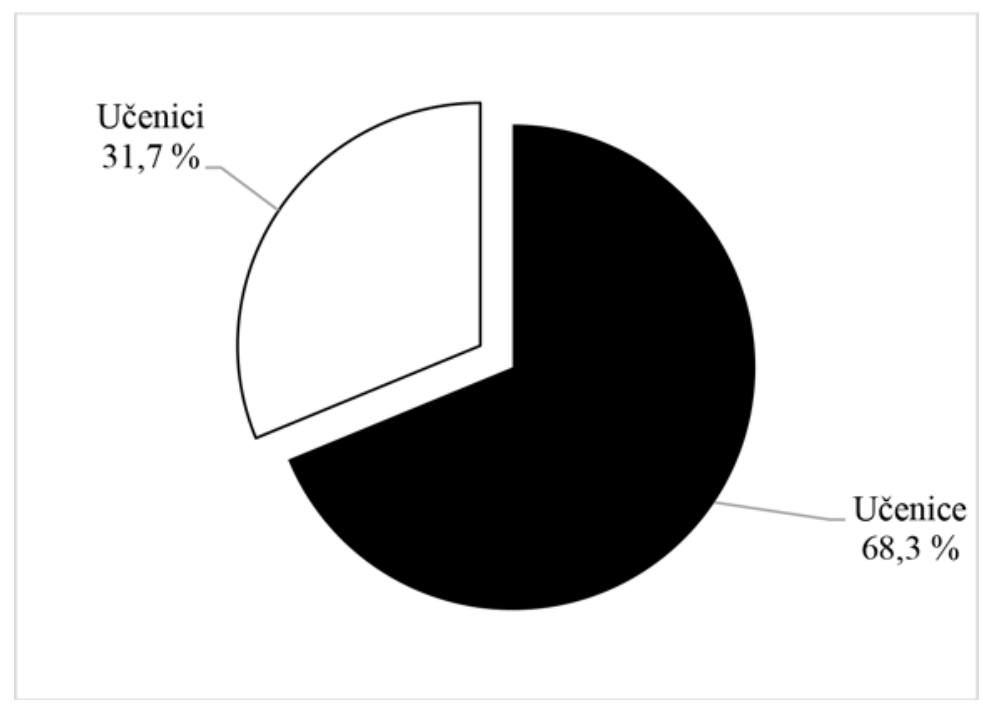

Grafikon 2. Postotak ispitanika prema spolu

\section{ISTRAŽIVAČKI INSTRUMENTI I POSTUPAK ISTRAŽIVANJA}

Anketni upitnik kojim su prikupljani podatci formiran je za potrebe istraživanja. U prvom dijelu, koji se sastoji od pet pitanja, prikupljeni su opći deskriptivni podatci o sudionicima (razred i spol) te je ispitivan njihov afinitet prema sadržajima kulturne i prirodne baštine i izloženost informacijama o istima. Drugi dio upitnika čini ukupno 31 tvrdnja, s ponuđenim odgovorima na skali Likertova tipa od pet stupnjeva.

Zadatak ispitanika bio je izraziti svoj stupanj slaganja s pojedinom tvrdnjom odabirom jedne od sljedećih mogućnosti: 1 - uopće se ne slažem, 2 - ne slažem se, 3 - niti se slažem, niti se ne slažem, 4 - slažem se, 5 - u potpunosti se slažem.

Korištene čestice odabrane su zbog činjenice da predstavljaju tvrdnje koje se često vezuju uz baštinu te je njima moguće najbolje odgovoriti na istraživačka pitanja. Također, kako bi se izbjegla nekonzistentnost u odgovaranju i osiguralo jasno razumijevanje čestica u upitniku, na samom početku upitnika nalazi se definicija kulturne i prirodne baštine: „Baština su sva prirodna i stvorena kulturna materijalna i duhovna dobra na određenom prostoru koja neka zajednica (društvo) nasljeđuje i kojima raspolaže. Baština je kolektivno dobro koje pripada (prošlosti, sadašnjosti i budućnosti) nama koliko i mi njoj. Baština je povijesna i dinamička kategorija i kao takva ona je kumulativna, pa u njoj nasljednicima ostaje ono što društvo procjenjuje kao vrijedno“ (Cifrić, 2014, str. 11).

Anketni upitnik podijeljen je učenicima osnovnih i srednjih škola Splitskodalmatinske, Šibensko-kninske te Zagrebačke županije uz pomoć profesora 
i psihologa zaposlenih u školama u kojima je provedeno istraživanje. Manji je broj upitnika prikupljen online, korištenjem Google obrazaca, uslijed zatvaranja škola zbog nacionalnog suočavanja s pandemijom bolesti Covid-19. Sudjelovanje je bilo dobrovoljno, a svi su sudionici rado sudjelovali u istraživanju.

\section{METODE OBRADE PODATAKA}

Prikupljeni podatci obrađivani su u programu IBM SPSS Statistics v.27. U okviru analize i obrade podataka izračunate su frekvencije $(N)$, aritmetičke sredine $(M)$ i standardne devijacije $(S D)$ pojedinih čestica. Za uspoređivanje prosječnih odgovora učenika osnovnih i srednjih škola upotrijebljeni su t-testovi, dok je za ispitivanje povezanosti pojedinih varijabli upotrijebljen Pearsonov koeficijent korelacije $(r)$.

\section{REZULTATI I RASPRAVA}

Kako bi se razvila svijest o značaju kulturne baštine, potrebno ju je upoznati prije svega na lokalnoj razini, a potom i na nacionalnoj razini. Poznavanjem kulturne i prirodne baštine zavičaja i Hrvatske učenici stječu temeljna znanja o okruženju u kojem žive, a time i razvijaju svijest o važnosti očuvanja baštinskih sadržaja koji predstavljaju blago naroda. Upravo poznavanje kulturne i prirodne baštine Hrvatske i svijest o važnosti njezine zaštite trebali bi biti važan dio školskih kurikula kako bi učenici postali zainteresirani za baštinu i njezine sadržaje te kako bi podigli razinu svoje svijesti o važnosti očuvanja baštine za budućnost.

U sklopu istraživanja stavova i znanja učenika o kulturnoj baštini, zanimalo nas je poznaju li učenici uopće baštinu svog zavičaja. Kako bismo odgovorili na ovo istraživačko pitanje, analizirali smo odgovore na pet pitanja prikazanih u Tablici 1. Zadatak učenika bio je izraziti svoje slaganje s pojedinom tvrdnjom na ljestvici od 1 (uopće se ne slažem) do 5 (u potpunosti se slažem). Pritom je zbog formulacije tvrdnji bilo potrebno obrnuto kodirati dvije čestice, koje su u tablici označene formatiranjem italic.

Prosječni rezultat na razini cjelokupnog uzorka iznosio je $M=3.24(S D=$ 0.445), što bi značilo da učenici i osnovne i srednje škole sveukupno procjenjuju kako osrednje poznaju sadržaje prirodne i kulturne baštine, no uočena je statistički značajna razlika između učenika osnovnih i srednjih škola, jer su srednjoškolci u prosjeku davali više odgovore $(t=3.657 ; \mathrm{p}<.001)$. Viši rezultat (aritmetičke sredine) u tablici ukazuje na pozitivnije stavove i razmišljanja o kulturnoj baštini. 
Tablica 1. Prosječni rezultati samoprocjena učenika osnovnih $(\mathrm{N}=157)$ i srednjih škola $(\mathrm{N}=165)$ o poznavanju kulturne i prirodne baštine

\begin{tabular}{lcccc}
\hline \multicolumn{1}{c}{ tvrdnje } & \multicolumn{2}{c}{ OŠ } & \multicolumn{2}{c}{ Sธ̌ } \\
\cline { 2 - 5 } & $\boldsymbol{M}$ & SD & M & SD \\
\hline $\begin{array}{l}\text { Jako dobro poznajem kulturnu i prirodnu } \\
\text { baštinu Hrvatske. }\end{array}$ & 2,94 & 1,004 & 3,17 & 0,801 \\
$\begin{array}{l}\text { Kulturna i prirodna baština mi nije zanimljiva, } \\
\text { ali poznajem osnovne sadržaje baštine. }\end{array}$ & 3,06 & 1,205 & 3,12 & 1,139 \\
$\begin{array}{l}\text { Poznajem samo neke sadržaje kulturne i } \\
\text { prirodne baštine Hrvatske. }\end{array}$ & 2,81 & 1,051 & 2,87 & 1,001 \\
$\begin{array}{l}\text { Poznajem samo kulturnu i prirodnu baštinu } \\
\text { Splitsko-dalmatinske županije. }\end{array}$ & 3,35 & 1,114 & 3,66 & 1,015 \\
$\begin{array}{l}\text { Znam više o kulturnoj i prirodnoj baštini } \\
\text { Splitsko-dalmatinske županije nego ostalih }\end{array}$ & 3,61 & 1,191 & 3,84 & 1,139 \\
dijelova Hrvatske. & & & & \\
\hline Ukupno & 3,15 & 0,429 & 3,33 & 0,444 \\
\hline
\end{tabular}

Legenda. $\mathrm{M}=$ aritmetička sredina; $\mathrm{SD}=$ standardna devijacija

To je posebno uočljivo u razlici prosječnih odgovora na tvrdnju Poznajem samo kulturnu i prirodnu baštinu Splitsko-dalmatinske županije $(t=2.614 ; p$ $=.009$ ), što ukazuje na to da srednjoškolci ipak poznaju baštinu ostalih regija Republike Hrvatske u većoj mjeri nego učenici osnovnih škola, koji bolje poznaju vlastiti zavičaj. Usto je zanimljivo primijetiti da se statistički značajna razlika uočava između srednjoškolaca i osnovnoškolaca, ali i učenika i učenica, u prosječnom slaganju s tvrdnjom Jako dobro poznajem kulturnu i prirodnu baštinu Hrvatske. Naime, čini se da učenici srednjih škola imaju bolje mišljenje o svom poznavanju kulturne i prirodne baštine $(t=2.311 ; p=.021)$ nego što to imaju učenici završnih razreda osnovne škole. Jednak trend primjećuje se i u spolnim razlikama, jer su učenici u prosjeku izražavali više slaganje s navedenom tvrdnjom nego učenice $(t=-2.343 ; p=.020)$.

Dobiveni rezultat logičan je i očekivan na tragu didaktičkog načela: od poznatoga $\mathrm{k}$ nepoznatom, od bližega $\mathrm{k}$ daljem. U skladu s tim, učenici najprije usvajaju kulturnu i prirodnu baštinu svoga zavičaja, a zatim postupno upoznaju kulturnu i prirodnu baštinu zavičajne mikroregije te kulturnu baštinu svoje države (De Zan, 2005). Zaključujemo kako su stariji učenici kroz kurikule različitih predmeta mogli, što je i logično, tijekom više godina školovanja bolje usvojiti znanja vezana uz baštinu.

Drugo pitanje koje nas je zanimalo u ovom istraživanju bilo je pokazuju li učenici interes i motiviranost za upoznavanje sadržaja kulturne baštine. Objašnjenje smo dobili analizom prosječnog odgovora na pitanje $U$ kolikom si stupnju zainteresiran/a za upoznavanje sadržaja kulturne i prirodne baštine?, pri čemu je 
zadatak sudionika bio odabrati jednu od ponuđenih pet opcija na skali Likertova tipa ( 1 - uopće nisam zainteresiran/a; 5 - jako sam zainteresiran/a). U prosjeku učenici u ovom istraživanju izražavaju umjereni stupanj zainteresiranosti za kulturnu i prirodnu baštinu Hrvatske $(M=3.19 ; S D=1.020)$, pri čemu srednjoškolci ipak ističu nešto veći interes od osnovnoškolaca (vidi Tablicu 2).

Tablica 2. Prosječni rezultati stupnja zainteresiranosti učenika osnovnih $(\mathrm{N}=157) \mathrm{i}$ srednjih škola $(\mathrm{N}=165)$ za sadržaje kulturne i prirodne baštine

\begin{tabular}{|c|c|c|c|c|}
\hline \multirow{2}{*}{ tvrdnje } & \multicolumn{2}{|c|}{ OŠ } & \multicolumn{2}{|c|}{ Š } \\
\hline & $M$ & $S D$ & $M$ & $S D$ \\
\hline \multirow{2}{*}{$\begin{array}{l}\text { U kolikom si stupnju zainteresiran/a za } \\
\text { upoznavanje sadržaja kulturne i prirodne } \\
\text { baštine? }\end{array}$} & 2,99 & 1,115 & 3,39 & 0,881 \\
\hline & \multicolumn{2}{|c|}{$t=3,587$} & \multicolumn{2}{|c|}{$p<.001$} \\
\hline
\end{tabular}

Legenda. $\mathrm{M}=$ aritmetička sredina; $\mathrm{SD}=$ standardna devijacija; $\mathrm{t}=$ rezultat $\mathrm{t}$-testa

Motivacija i interes utječu na ljudsko ponašanje i potiču pozitivnu znatiželju u ponašanju i djelovanju u mnogim područjima života. Nedostatak motivacije i interesa jedan je od problema u odgoju i obrazovanju djece i mladih. Govoreći o motivaciji, Sternberg i Williams (2009) ističu kako ona predstavlja unutarnju snagu, za koju navode da je osobna mentalna sposobnost koja pojedincu pomaže u postizanju ciljeva koje je sebi zadao. Kognitivni procesi i motivacija imaju središnju ulogu u ljudskom učenju (Bandura, 1977), a isto tako za motivaciju se navodi kako je ona jedan od najvažnijih čimbenika u procesu učenja i stjecanja akademskih postignuća (Alderman, 2004). Stoga ne možemo zanemariti važnost interesa i motivacije u usvajanju sadržaja učenja. Jedan od razloga općenito za slabljenje motivacije za učenje jest činjenica što učenici uopće ne smatraju usvajanje zadanih školskih sadržaja svojim ciljem (Razum, 2003). Trebalo bi učenicima osvijestiti ciljeve učenja, pa tako i učenja vezanog uz sadržaje kulturne i prirodne baštine kako bismo pobudili intrinzičnu motivaciju kod učenika. Govoreći o motivaciji, navode se tri tipa motivacije: intrinzična motivacija, ekstrinzična motivacija i amotivacija. Intrinzična motivacija odnosi se na radnje koje pojedinac voli raditi i koje smatra zanimljivima, dok se ekstrinzična motivacija odnosi na radnje koje su potaknute vanjskim faktorima, poput ishoda koji se nagrađuju. O amotivaciji govori se kao o stanju nezainteresiranosti za sudjelovanjem (Deci i Ryan, 2000).

Rezultati istraživanja pokazuju kako su učenici tek osrednje zainteresirani za baštinu, stoga u kvalitetnoj interakciji s učenicima trebalo bi raditi na motivaciji i interesu učenika kako bi rado, zainteresirano i s lakoćom usvajali gradivo vezano uz sadržaje baštine. Kvalitetnom i prikladnom edukacijom profesori su u mogućnosti stvarati podlogu za razvoj intrinzične motivacije kod učenika, čime će na najbolji način unaprjeđivati njihovu motivaciju u učenju kako bi porastao interes učenika prema prirodnoj i kulturnoj baštini. 
Iduće pitanje na koje smo nastojali odgovoriti u istraživanju ticalo se uloge akademskog obrazovanja u pridavanju značaja temi kulturne i prirodne baštine. Naime, zanimalo nas je pridaje li se u okviru odgojno-obrazovnog rada dovoljno pozornosti sadržajima kulturne baštine i na kojim nastavnim predmetima te shvaćaju li učenici da je to važno. Tijekom odgoja i obrazovanja učenika u školama jedan od važnih ciljeva podučavanja trebao bi biti priprema učenika za život u njihovu društvenom i prirodnom okruženju, prepunom raznolikih sadržaja. Upravo iz tog razloga nastavni proces treba biti fleksibilan, interdisciplinaran te povezan sa stvarnim životom (Jensen, 2003). Kurikul u osnovnim i srednjim školama predviđa povezivanje ishoda učenja unutar sadržaja različitih nastavnih predmeta, a ishodi međupredmetnih tema također omogućavaju povezivanje različitih sadržaja vezanih uz prirodnu i kulturnu baštinu.

Odgovor na ovo pitanje utvrdili smo analizom prosječnih odgovora na šest tvrdnji navedenih u Tablici 3. Kao i u prvom slučaju (te ostalim istraživačkim ciljevima koji slijede), zadatak sudionika bio je izraziti svoje slaganje sa svakom od tvrdnji na skali od 1 (uopće se ne slažem) do 5 (u potpunosti se slažem). Prosječni rezultat iznosio je $M=3.21(S D=0.618)$, no opet se uočava statistički značajna razlika u rezultatima između srednjoškolaca i osnovnoškolaca.

Tablica 3. Prosječni rezultati samoprocjena učenika osnovnih $(\mathrm{N}=157)$ i srednjih škola $(N=165)$ o pridavanju značaja temama kulturne i prirodne baštine u obrazovanju

\begin{tabular}{lrrrc}
\hline \multirow{2}{*}{ tvrdnje } & \multicolumn{2}{c}{ OŠ } & \multicolumn{2}{c}{ SŠ } \\
\cline { 2 - 5 } & $\boldsymbol{M}$ & $\boldsymbol{S D}$ & $\boldsymbol{M}$ & $\boldsymbol{S D}$ \\
\hline $\begin{array}{l}\text { U školi sam saznao/la jako puno o kulturnoj i } \\
\text { prirodnoj baštini i njezinoj vrijednosti. }\end{array}$ & 3,48 & 1,047 & 3,58 & 0,995 \\
$\begin{array}{l}\text { U školi sam saznao/la jako puno o važnosti kulturne } \\
\text { i prirodne baštine i njezinu očuvanju. }\end{array}$ & 3,47 & 1,113 & 3,57 & 0,989 \\
$\begin{array}{l}\text { O kulturnoj i prirodnoj baštini najviše sam saznao/la } \\
\text { na nastavi hrvatskog jezika i/lili povijesti. }\end{array}$ & 3,29 & 1,110 & 3,59 & 1,120 \\
$\begin{array}{l}\text { O kulturnoj i prirodnoj baštini najviše sam saznao/la } \\
\text { na nastavi vjeronauka. }\end{array}$ & 2,31 & 1,090 & 1,95 & 0,987 \\
$\begin{array}{l}\text { O kulturnoj i prirodnoj baštini najviše sam saznao/ } \\
\text { la na nastavi umjetničkih predmeta (likovna kultura, } \\
\text { glazbena kultura). }\end{array}$ & 2,54 & 1,212 & 3,56 & 1,078 \\
$\begin{array}{l}\text { Svijest o kulturnoj i prirodnoj baštini i zaštiti } \\
\text { baštine potrebno je njegovati već u predškolskim } \\
\text { ustanovama. }\end{array}$ & 3,43 & 1,210 & 3,76 & 1,154 \\
\hline Ukupno & 3,08 & 0,616 & 3,34 & 0,596 \\
\hline
\end{tabular}

Legenda. $\mathrm{M}=$ aritmetička sredina; $\mathrm{SD}=$ standardna devijacija 
Učenici srednjih škola u prosjeku su izražavali više slaganje s navedenim tvrdnjama nego učenici osnovnih škola $(t=3.707 ; p<.001)$. Međutim, zanimljivo je uočiti obrnuti smjer razlike kod odgovora na tvrdnju koja se tiče nastave vjeronauka. Naime, iako se kod obiju skupina radi o tvrdnji koja je najniže ocijenjena u čitavom upitniku, ukazujući na to da učenici manje saznaju o kulturnoj i prirodnoj baštini na nastavi vjeronauka nego na ostalim predmetima ili iz drugih izvora informacija, čini se da je vjeronauk nešto značajniji u educiranju o tim temama u osnovnoj nego srednjoj školi $(t=-3.060 ; p=.002)$.

Istraživanje poznavanja sadržaja baštine Šibensko-kninske županije od strane učenika osnovnih škola te zastupljenost baštinskih sadržaja u nastavi glazbene i likovne kulture ukazali su na zanemarenost baštinskih sadržaja u odgoju i obrazovanju općenito, a posebno u nastavi umjetničkih područja. Drugim riječima, rezultati ovog istraživanja pokazali su kako mladi nedovoljno poznaju baštinu kraja u kojemu žive (Dobrota i Kuščević 2008). Vrijednost kulturne baštine i potreba njezina dugoročnog očuvanja i zaštite neupitni su u svim razvijenim društvima suvremenog svijeta. Bez očuvane kulturne baštine ne može se govoriti o kulturi, povijesti, kolektivnom sjećanju i identitetu nekoga naroda u cjelini i svakog pojedinog njegova člana.

Nadovezujući se na temu pridavanja značaja kulturnoj baštini, zanimalo nas je i u kolikoj su mjeri učenici svjesni važnosti njezina očuvanja. Kako bismo odgovorili na ovo pitanje, analizirali smo prosječne odgovore na šest tvrdnji prikazanih u tablici koja slijedi. Pritom je bilo potrebno obrnuto kodirati jednu od čestica, koja je u Tablici 4 zapisana u formatu italic.

Tablica 4. Prosječni rezultati samoprocjena učenika osnovnih $(\mathrm{N}=157)$ i srednjih škola $(N=165)$ o važnosti očuvanja kulturne i prirodne baštine

\begin{tabular}{|l|c|c|c|c|}
\hline \multirow{2}{*}{ tvrdnje } & \multicolumn{2}{|c|}{ OŠ } & \multicolumn{2}{|c|}{ SŠ } \\
\cline { 2 - 5 } & $\boldsymbol{M}$ & $\boldsymbol{S D}$ & $\boldsymbol{M}$ & $\boldsymbol{S D}$ \\
\hline $\begin{array}{l}\text { Svijest o kulturnoj i prirodnoj baštini i zaštiti } \\
\text { baštine potrebno je njegovati već u predškolskim } \\
\text { ustanovama. }\end{array}$ & 3,43 & 1,210 & 3,76 & 1,154 \\
$\begin{array}{l}\text { Zaštita kulturne i prirodne baštine jedino je moguća } \\
\text { ako su svi u nekom društvu svjesni važnosti baštine. } \\
\text { Briga o kulturnoj i prirodnoj baštini trebala bi se ticati } \\
\text { svih ljudi u nekoj zemlji. }\end{array}$ & 3,64 & 1,132 & 4,11 & 0,884 \\
$\begin{array}{l}\text { Naša kulturna i prirodna baština nije dovoljno } \\
\text { zaštićena. }\end{array}$ & 3,51 & 1,141 & 4,30 & 0,899 \\
$\begin{array}{l}\text { Ljudi su svjesni da uništavaju kulturnu i prirodnu } \\
\text { baštinu, ali ih za to nije briga. }\end{array}$ & 3,92 & 1,086 & 3,76 & 1,059 \\
$\begin{array}{l}\text { Uopće me ne zanimaju problemi uništavanja kulturne } \\
\text { i prirodne baštine, neka se o tome brinu stručnjaci. }\end{array}$ & 3,80 & 1,192 & 4,04 & 0,926 \\
\hline Ukupno & 3,71 & 0,719 & 3,97 & 0,639 \\
\hline
\end{tabular}

Legenda. $\mathrm{M}=$ aritmetička sredina; $\mathrm{SD}=$ standardna devijacija 
Odgovorno upravljanje baštinom pretpostavlja zaštitu i konzervaciju, odnosno očuvanje kulturnih i prirodnih dobara. Baština sigurno ne može opstati bez baštinika i njihove svijesti o važnosti očuvanja baštine. Odnos prema kulturnoj i prirodnoj baštini odnos je prema prošlosti, sadašnjosti i budućnosti. U sadašnjosti baština pripada svima, što uključuje pravo na korištenje, no isto tako i obvezu i dužnost očuvanja baštine. Zaštita kulturne i prirodne baštine postala je posebno važna u shvaćanjima vezanima uz koncept održivog razvoja (Maroević, 2001). Globalizacija te intenzivni razvoj turizma stvara prijetnju prirodnoj i kulturnoj baštini, zato se danas o prirodnoj i kulturnoj baštini sve više razmišlja u kontekstu održivog razvoja.

„Održivi razvoj u zaštiti kulturne baštine je kontrolirani razvoj, ograničen tako da ne izaziva njezinu degradaciju. On pretpostavlja poznavanje resursa baštine, njihovo iskorištavanje do odredivih granica i ograničavanje razvoja u cilju njihova očuvanja“" (Maroević, 2001, str. 235). Bez solidarnosti između kulturnih i baštinskih institucija te različitih javnih institucija zaštita baštine bila bi otežana jer stupanj zaštite ovisi o širem sociološkom kontekstu i važnosti koju društvo pridaje zaštiti prirodnih i kulturnih resursa. Stupanj svjesnosti društva o zaštiti baštine također ovisi o senzibiliziranosti prema sadržajima baštine, na što bi trebalo utjecati planiranim akcijama podizanja svijesti o baštini. Zaštitu baštine trebalo bi promovirati podizanjem svijesti te propitkivanjem odgovornosti svih, i to već od najranije dobi kako bismo došli do kvalitetnijih rješenja u zaštiti i očuvanju kulturne i prirodne baštine te $u$ konačnici do podizanja svijesti o povezanosti njezina utjecaja na održivi razvoj.

Učenici i osnovnih i srednjih škola uglavnom se slažu oko tvrdnji vezanih uz važnost očuvanja prirodne i kulturne baštine, ali prosječni odgovor na ovo pitanje nešto je viši nego u prethodnim slučajevima $(M=3.84 ; S D=0.690)$ te se opet uočava razlika između učenika srednjih i osnovnih škola. Srednjoškolci izražavaju značajno više slaganje s tvrdnjama koje se tiču važnosti očuvanja kulturne baštine $(t=3.399 ; p<.001)$. Pritom je ta činjenica najizraženija za tvrdnje koje se tiču uloge pojedinca: Zaštita kulturne i prirodne baštine jedino je moguća ako su svi u nekom društvu svjesni važnosti baštine $(t=4.126 ; p<$ .001) i Briga o kulturnoj i prirodnoj baštini trebala bi se ticati svih ljudi u nekoj zemlji $(t=2.769 ; p=.006)$.

Sličan trend uočava se u odgovoru na iduće pitanje, jesu li učenici svjesni povezanosti razvoja gospodarstva s očuvanjem i prezentacijom kulturne baštine s obzirom na to da baština u 21. stoljeću predstavlja važan preduvjet nacionalnog i gospodarskog razvitka društva u cjelini. U tu svrhu smo analizirali odgovore na sljedećih pet tvrdnji u upitniku, koje su prikazane u Tablici 5. Zbog formata tvrdnje bilo je potrebno obrnuto kodirati bodovanje posljednje čestice, stoga je ona u tablici označena formatom italic. 
Tablica 5. Prosječni rezultati samoprocjena učenika osnovnih $(\mathrm{N}=157)$ i srednjih škola $(\mathrm{N}=165)$ o povezanosti kulturne baštine i nacionalnog gospodarstva

\begin{tabular}{lcccc}
\hline \multirow{2}{*}{ tvrdnje } & \multicolumn{2}{c}{ OŠ } & \multicolumn{2}{c}{ SŠ } \\
\cline { 2 - 6 } & M & SD & M & SD \\
\hline $\begin{array}{l}\text { Prirodna i kulturna baština može biti važan dio } \\
\text { razvoja društva. }\end{array}$ & 3,68 & 1,127 & 4,22 & 0,856 \\
$\begin{array}{l}\text { Prirodna i kulturna baština preduvjet je razvoja } \\
\text { društva u budućnosti. }\end{array}$ & 3,54 & 1,077 & 3,82 & 1,020 \\
$\begin{array}{l}\text { Turistički razvoj zavičaja ovisi o kulturnoj i } \\
\text { prirodnoj baštini. }\end{array}$ & 3,93 & 1,007 & 4,07 & 0,989 \\
$\begin{array}{l}\text { Gospodarski razvoj zavičaja ovisi o kulturnoj i } \\
\text { prirodnoj baštini. }\end{array}$ & 3,45 & 1,065 & 3,56 & 1,061 \\
$\begin{array}{l}\text { Prirodna i kulturna baština je nevažna za društvo i } \\
\text { njegov razvoj. }\end{array}$ & 3,69 & 1,180 & 4,04 & 1,123 \\
\hline Ukupno & 3,66 & 0,763 & 3,94 & 0,672 \\
\hline
\end{tabular}

Legenda. $\mathrm{M}=$ aritmetička sredina; $\mathrm{SD}=$ standardna devijacija

Prosječni odgovor na ova pitanja iznosio je $M=3.80$ (SD $=0.731)$, pri čemu je ponovno prisutna statistički značajna razlika u odgovorima između učenika srednjih i osnovnih škola $(t=3.521 ; p<.001)$. Čini se da srednjoškolci jasnije shvaćaju važnost prirodne i kulturne baštine u razvoju društva nego osnovnoškolci, jer posebno izražavaju više slaganje s tvrdnjom Prirodna i kulturna baština može biti važan dio razvoja društva $(t=4.827 ; p<.001)$.

U izazovima suvremenog doba baština postaje resurs budućnosti, stoga postaje važno odnositi se prema baštini na aktivan način. Baština ne smije biti samo sjećanje na prošlost te se aktivnosti vezane uz baštinu ne mogu odnositi samo na zaštitu baštine iako je zaštita baštine značajno društveno pitanje. Kulturna i prirodna baština može osnažiti nacionalni gospodarski razvoj, zato se ovaj aspekt baštine ne može zanemarivati u odgoju i obrazovanju djece i mladih, već ga treba kontinuirano osvještavati u sustavima odgoja i obrazovanja. Turizam kao jedan od pokretača nacionalnog gospodarstva usmjerava se uglavnom na dva vida turističkog gospodarstva te koristi njihove resurse, a to su kulturni i prirodni resursi (Gredičak, 2008). Možemo zaključiti kako učenici srednje škole s obzirom na to da su stariji, što je i očekivano, bolje shvaćaju društvene odnose te važnost koju prirodna i kulturna baština ima u razvoju nacionalnog gospodarstva.

Iduće istraživačko pitanje bilo je usmjereno na ispitivanje svijesti učenika o važnosti kulturne baštine u očuvanju identiteta naroda. Kulturna i prirodna baština te različite kulturne tradicije vezane uz društvo utječu na nacionalni osjećaj ljudi toga društva. Na taj način utječe se na stvaranje društvenoga 
nacionalnog identiteta. „Nacionalni identitet jedan je od kolektivnih identiteta i predstavlja autorefleksiju nacionalne zajednice, njezin odgovor na pitanja tko su pripadnici te zajednice, kakva je njihova (pri)povijest, aktualna zbilja i perspektiva“" (Babić, 2018, str. 179).

Povezanost kulture i identiteta te identitetska pitanja potkraj 20. i početkom 21. stoljeća postaju sve aktualnija u društvenoj teoriji i praksi (Georgievski i Žoglev, 2014). Globalizacijski procesi postaju nužni i nezaustavljivi fenomeni suvremenog svijeta koji se očituju u društvenim promjenama, što se reflektira i u područje kulture. Društvo i kultura međusobno su povezani jer kultura zapravo prezentira život nekog društava s njegovim vjerovanjima, idejama, simbolima, politikom, umjetnošću, obrazovanjem. Tako kultura pojedinog naroda kristalizira njegovu srž, odnosno definira njegov identitet. Globalizacijom društva u suvremenom svijetu rastaču se tradicionalna uporišta, a identiteti koji su ljudima u prošlosti predstavljali uporišta u promišljanju sebe i zajednice gube prethodna značenja (Babić, 2018). U eri globalizacije pitanje identiteta postaje bitno kako bi se očuvale osobitosti društava koja postaju dio globalnog svijeta. Narodi koji imaju mali broj stanovnika i nevelik teritorij moraju biti svjesni kako globalizacija razara njihov identitet. Mali narodi postaju nesvjesni vlastitog identiteta te prihvaćaju tuđi identitet, čime malim narodima prijeti opasnost od nestajanja.

U Hrvatskoj uz većinsko hrvatsko stanovništvo živi i manji broj etničkih manjina. Neke od nacionalnih manjina čine Talijani, Romi, Srbi i Bošnjaci, a same manjine disperzirane su po različitim gradovima, regijama i županijama Hrvatske te se razlikuju po vjeroispovijesti i različitoj kulturnoj organiziranosti te tradiciji koju baštine. Odgojno-obrazovne institucije sustavno trebaju raditi na razvijanju svijesti i ponosa učenika o pripadnosti vlastitom narodu, no isto tako moraju educirati mlade generacije o različitim oblicima ekstremizma bilo nacionalnog, etničkog ili religijskog. Burai ističe kako se upravo u školi uče osnove društveno-odgovornog ponašanja u demokratskom društvu, gdje pojedinac treba biti svjestan svoje kulture, vrijednosti i tradicije, ali i tolerantan prema drugom i drugačijem (Burai, 2016).

Odgovor na pitanje o važnosti kulturne baštine u očuvanju nacionalnog identiteta dobili smo analiziranjem prosječnih odgovora učenika na pet tvrdnji koje su prikazane u Tablici 6. Prosječni odgovor učenika na navedene tvrdnje iznosio je $M=4.04(S D=0.825)$, što je ujedno najviši prosječni odgovor u cijelom upitniku, iz čega možemo zaključiti da su učenici svjesni važnosti kulturne i prirodne baštine za nacionalni identitet. Pritom se čini da ta svijest raste s dobi i obrazovanjem, jer srednjoškolci izražavaju statistički značajno više slaganje sa svih pet tvrdnji u odnosu na osnovnoškolce $(t=4.385 ; p<.001)$. Možemo zaključiti kako su učenici svjesni važnosti nacionalne prirodne i kulturne baštine jer ona omogućava našem narodu prepoznatljivost u svijetu, ali isto tako može biti most za upoznavanje drugih kultura. 
Tablica 6. Prosječni rezultati samoprocjena učenika osnovnih $(\mathrm{N}=157)$ i srednjih škola $(\mathrm{N}=165)$ o važnosti kulturne baštine u očuvanju nacionalnog identiteta

\begin{tabular}{lcccc}
\hline \multicolumn{1}{c}{ tvrdnje } & \multicolumn{2}{c}{ OŠ } & \multicolumn{2}{c}{ SŠ } \\
\cline { 2 - 5 } & $\boldsymbol{M}$ & SD & M & SD \\
\hline $\begin{array}{l}\text { Danas, kada živimo u vremenu globalizacije, itekako } \\
\text { moramo voditi računa o nacionalnim dobrima } \\
\text { baštine. }\end{array}$ & 3,82 & 1,049 & 4,13 & 0,912 \\
$\begin{array}{l}\text { Prirodna i kulturna baština omogućuje našem narodu } \\
\text { prepoznatljivost u svijetu. }\end{array}$ & 3,97 & 1,077 & 4,33 & 0,926 \\
$\begin{array}{l}\text { Prirodna i kulturna baština može biti most prema } \\
\text { upoznavanju drugih kultura. }\end{array}$ & 3,74 & 1,093 & 4,02 & 0,975 \\
$\begin{array}{l}\text { Važno je poznavati kulturnu i prirodnu baštinu svog } \\
\text { naroda. }\end{array}$ & 3,93 & 1,139 & 4,35 & 0,810 \\
$\begin{array}{l}\text { Prirodna i kulturna baština važna je u očuvanju } \\
\text { nacionalnog identiteta. }\end{array}$ & 3,72 & 1,113 & 4,30 & 0,939 \\
\hline Ukupno & 3,83 & 0,882 & 4,23 & 0,718 \\
\hline Legenda. $\mathrm{M}=$ aritmetička sredina; SD = standardna devijacija & & & \\
\hline
\end{tabular}

Nismo pronašli istraživanja koja govore o kulturnoj baštini i identitetu vezana uz razmišljanja učenika. U istraživanju u kojem su se ispitivali stavovi studenata pete godine učiteljskoga studija Učiteljskoga fakulteta Sveučilišta u Zagrebu o mogućim ciljevima i zadatcima koji se mogu ostvariti spoznavanjem sadržaja o kulturnoj baštini „Najviše ispitanih studenata smatra da bi takvi sadržaji mogli utjecati na razvijanje ljubavi prema domovini kod učenika, ali i na povećanje njihovih interesa i odgovornosti za kulturnu baštinu općenito kao i za društvo i kulturu koja ih okružuje. Također, većina studenata uočava potrebu da se takvim sadržajima kod učenika razvijaju interkulturalne kompetencije te pozitivan odnos prema pripadnicima drugih kultura“" (Vasilj i Letina 2019, str. 22-23).

Kreativna interpretacija nasljeđa, baštine, jedan je od važnih zahtijeva suvremenoga doba. Baština može vrlo uspješno potaknuti kreativni razvoj učenika, a kulturna i prirodna baština može se upotrijebiti kao izvor za inspiraciju i stvaranje novih kreativnih tvorevina, posebno na nastavi umjetničkih područja. Zato je posljednjih pet tvrdnji u upitniku imalo za svrhu provjeriti utječe li doticaj s kulturnom baštinom na poticanje kreativnosti učenika. Pitanja koja smo postavili učenicima bila su sljedeća: U komunikaciji s kulturnom i prirodnom baštinom mogu razvijati svoju kreativnost. Kroz kulturnu i prirodnu baštinu ljudi pokazuju ostvarenost svoje kreativnosti i stvaralaštva. Volim izražavati svoju kreativnost kroz umjetnički izraz na tragu kulturne i prirodne baštine (likovni, glazbeni, baština kao literarni poticaj). Prirodna i kulturna baština me ne 
potiče na kreativno izražavanje. Kulturna i prirodna baština mi uvijek omogućava da pokažem svoju kreativnost. Prosječni odgovor iznosio je $M=3.21$ (SD $=0.817$ ), no nije bilo statistički značajne razlike u odgovorima učenika srednjih i osnovnih škola. Možemo zaključiti da bi baštinu trebalo bolje iskoristiti kao poticaj za kreativno izražavanje učenika i u osnovnoj školi i u srednjoj školi.

U ovom istraživanju, uz interes učenika i učenica prema temi baštine, zanimalo nas je utječe li posjećivanje muzeja, galerija i arheoloških lokaliteta na interes učenika prema poznavanju i doživljavanju baštine. Također nas je zanimalo koliko često učenici posjećuju navedene sadržaje. Istraživanje je pokazalo kako najviše učenika ističe da takve institucije posjećuju jednom godišnje $(53,7$ \%), a tek manji broj njih (5,6 \%) to čini pet ili više puta godišnje. Navedeni rezultat usporedili smo s rezultatom istraživanja Kuščević i sur. provedenom 2009. godine. U navedenom istraživanju utvrđeno je kako učenici izrazito slabo posjećuju muzeje i galerije. Muzeje i galerije često posjećivalo je samo 5,6 \% učenika, katkada $36,6 \%$, a $57,8 \%$ učenika nikada nije odlazilo niti u muzej niti u umjetničku galeriju niti na likovne izložbe. U odnosu na 2009. godinu sada ipak gotovo polovica ispitanih učenika odlazi jednom godišnje u navedene institucije.

$\mathrm{U}$ svrhu ispitivanja povezanosti te učestalosti s interesom za sadržaje baštine, izračunali smo Pearsonov koeficijent korelacije između dviju varijabli, tj. odgovora na pitanja (Koliko često posjećuješ muzeje, galerije ili arheološke lokalitete kako bi upoznao/la sadržaje kulturne baštine? i U kolikom si stupnju zainteresiran/a za upoznavanje sadržaja kulturne i prirodne baštine?). Rezultati ukazuju na postojanje statistički značajne umjerene i pozitivne korelacije $(r=.480 ; p<.001)$. Drugim riječima, učestalije posjećivanje institucija poput muzeja, galerija i arheoloških lokaliteta povezano je s većim interesom za upoznavanjem sadržaja kulturne i prirodne baštine.

\section{ZAKLJUČAK}

Poštovanje kulturne i prirodne baštine civilizacijska je tekovina i pitanje društvene odgovornosti te svakako i pitanje nužnosti opstanka našeg naroda u suvremenom svijetu. O baštini danas možemo govoriti s različitih stajališta, što uključuje identitet, održivi razvoj, kreativnost, očuvanje baštine te gospodarski razvoj. Suvremeni školski kurikul prepoznaje važnost i vrijednost baštinskih sadržaja u odgoju i obrazovanju djece i mladih te sadržaje prirodne i kulturne baštine uključuje u sadržaje različitih nastavnih predmeta.

U ovom istraživanju dobili smo uvid u stavove i razmišljanja učenika vezana uz prirodnu i kulturnu baštinu. Analizom podataka uočavamo da učenici srednjih škola imaju bolje mišljenje o svom poznavanju kulturne i prirodne baštine $(t=2.311 ; p=.021)$ nego što to imaju učenici završnih razreda osnovne škole. Sličan rezultat utvrdili smo i u spolnim razlikama, jer su se učenici u 
prosjeku više slagali s tvrdnjom nego učenice $(t=-2.343 ; p=.020)$. Prosječni rezultati stupnja zainteresiranosti učenika osnovnih i srednjih škola za sadržaje kulturne i prirodne baštine ukazuju na to kako u prosjeku učenici u ovom istraživanju izražavaju osrednji stupanj zainteresiranosti za kulturnu i prirodnu baštinu Hrvatske $(M=3.19 ; S D=1.020)$, pri čemu su srednjoškolci nešto više zainteresirani od osnovnoškolaca.

Srednjoškolski učenici bolje prepoznaju vrijednost prirodne i kulturne baštine u okviru rada odgojno-obrazovnih ustanova u sadržajima različitih nastavnih predmeta, ali učenici osnovne škole izražavaju veći utjecaj nastave vjeronauka u stjecanju znanja o sadržajima baštine nego što je to slučaj kod učenika srednjih škola. I srednjoškolski i osnovnoškolski učenici uglavnom se slažu oko tvrdnji vezanih uz važnost očuvanja prirodne i kulturne baštine. Međutim, učenici srednjih škola izražavaju značajno više slaganje s tvrdnjama koje se tiču zaštite baštine $(t=3.399 ; p<.001)$, što dolazi do izražaja u tvrdnjama koje ističu važnost društvene odgovornosti, te o očuvanju baštine više razmišljaju kao o sociološkom konceptu odgovornosti pojedinca, ali i svih ljudi.

Prosječni rezultati procjena učenika osnovnih i srednjih škola o važnosti kulturne baštine u očuvanju nacionalnog identiteta ukazuju na to kako su učenici izrazito svjesni vrijednosti kulturne baštine u očuvanju nacionalnog identiteta. U ovom istraživanju utvrdili smo kako svijest učenika raste s dobi i obrazovanjem. Učenici srednje škole izražavaju statistički značajno više slaganje sa svih pet tvrdnji vezanih uz prirodnu i kulturnu baštinu i nacionalni identitet $\mathrm{u}$ odnosu na učenike osnovne škole $(t=4.385 ; p<.001)$.

Prirodna i kulturna baština trebala bi biti bolje iskorištena za kreativno izražavanje učenika kroz različite nastavne predmete. Istraživanje je pokazalo kako i mlađi i stariji učenici nisu previše motivirani za kreativno izražavanje baštinskih sadržaja. Analizom rezultata utvrdili smo kako učenici nisu osobito zainteresirani za posjećivanje različitih kulturnih institucija te da navedene institucije više od polovice učenika $(53,7$ \%) posjećuje samo jedanput godišnje. Dubljom analizom rezultata utvrđeno je postojanje statistički značajne pozitivne korelacije $(r=.480 ; p<.001)$ kod analize odgovora učenika koji posjećuju kulturne institucije. Češće posjećivanje kulturnih institucija povezano je s većim interesom učenika za sadržaje kulturne i prirodne baštine.

Rezultati dobiveni ovim istraživanjem daju prilog istraživanjima vezanim uz proučavanje kulturne i prirodne baštine u području odgoja i obrazovanja. Učenik danas postaje aktivni sudionik odgojno-obrazovnog procesa, zato bi razmišljanja, iskustva i stavovi učenika trebali pridonijeti kritičkom promišljanju baštinskih sadržaja u obveznom obrazovanju. U budućim istraživanjima preporučuje se uključiti procjene, stavove i razmišljanja učitelja i profesora o prirodnoj i kulturnoj baštini kako bi različiti pogledi sudionika uključenih u odgoj i obrazovanje na tragu baštine osvijestili dijaloški okvir baštine u različitim 
područjima razvoja društva. Nadamo se da će ovo istraživanje potaknuti razmišljanja o baštini kao o ulogu u budućnost.

\section{LITERATURA}

Alderman, M. K. (2004). Motivation for achievement: Possibilities for teaching and learning (2nd ed.). Lawrence Erlbaum Associates Publishers.

Babić, D. (2018). Talijani u požeško-slavonskoj županiji između asimilacije i očuvanja identiteta. Radovi Zavoda za znanstveni i umjetnički rad u Požegi, 7, 177-196. https://doi.org/10.21857/m3v76t678y

Babić, D., Vatan Kaptan, M. i Masriera Esquerra, C. (2019). Heritage Literacy: A Model to Engage Citizens in Heritage Management. U O. Šćitaroci, B. Bojanić i A. Mrđa (ur.), Cultural Urban Heritage. Development, Learning and Landscape Strategies (str. 1-18). Cham: Springer.

Bandura, A. (1997). Self-Efficacy: The Exercise of Control. Freeman.

Boljanović, A. M. (2011). Normizacija u području kulturne baštine. Godišnjak zaštite spomenika kulture Hrvatske, 35(35), 51-62. https://hrcak.srce.hr/117157

Brajčić, M. i Kuščević, D. (2008). Prirodna i kulturna baština u kontekstu učenja za održivi razvoj i nastava likovne kulture. U V. Uzelac, L. Vujičić, (ur.), Cjeloživotno učenje za održivi razvoj (str. 157-162). Svezak 2. Rijeka: Sveučilište u Rijeci, Učiteljski fakultet u Rijeci.

Burai, R. (2016). Sukonstrukcija interkulturalnog kurikuluma. komparacija određenih obilježja hrvatske kulture kod srednjoškolaca i njihovih nastavnika (Hofstedeov model). Školski vjesnik, 65(2), 181-208. https://hrcak.srce.hr/177387

Cifrić, I. (2010). U povodu godišnjaka Titius: zaštita prirodne i kulturne baštine. Godišnjak Titius, 3(3), 243-259. https://hrcak.srce.hr/117715

Cifrić, I. (2014). Očuvanje baštine u kontekstu Europske unije. Adrias, (20), 9-19.

Cifrić, I. i Trako Poljak, T. (2014). Baština čovječanstva - održanje, korištenje i stvaranje. Godišnjak Titius, 6-7(6-7), 25-36. https://hrcak.srce.hr/149238

Čukelj, Z. (2009). Mogućnosti stjecanja znanja i spoznaja o prirodnoj i kulturnoj baštini u osnovnim školama Republike Hrvatske. Socijalna ekologija, 18(3-4), 267-288. https://hrcak.srce.hr/54109

Deci, E. L. i Ryan, R. M. (2000). The "what" and "why" of goal pursuits: Human needs and the self-determination of behavior. Psychological Inquiry, 11(4), 227-268. https://doi. org/10.1207/S15327965PLI1104_01

De Zan, I. (2005). Metodika Prirode i društva. Školska knjiga.

Dobrota, S. i Kǔšcević, D. (2008). Zavičajna baština šibensko-kninske županije - refleksije u nastavi glazbene i likovne kulture. Godišnjak Titius,1 (1), 259-272. https://hrcak.srce.hr/111980

Fulcher, J. i Scott, J. (2011). Socialization, Identity and Interaction in Sociology. Oxford Univesity Press.

Georgievski, P. i Žoglev, Z. (2014). Uloga kulture u formiranju osobnog i društvenog identiteta u procesu socijalizacije. Godišnjak Titius, 6-7(6-7), 517-528. 
Gredičak, Tatjana (2009). Kulturna baština i gospodarski razvitak Republike Hrvatske, Ekonomski pregled, 60(3-4), 196-218.

Jensen, E. (2003). Super-nastava: Nastavne strategije za kvalitetnu školu i uspješno učenje. Educa.

Kostović-Vranješ, V. (2015). Baština - polazište za promicanje odgoja i obrazovanja za održivi razvoj. Školski vjesnik, 64(3), 439-452. https://hrcak.srce.hr/151365

Kostović-Vranješ, V. i Jukić, T. (2011). Ekološka pismenost, sodobna vzgojno-izobraževalna paradigma. U M. Duh (ur.), Raziskovalni vidiki ekologije v kontekstu edukacije: znanstvena monografija, (str. 71-83). Univerza v Mariboru: Pedagoška fakulteta, Rakičan: RIS Dvorec.

Kostović-Vranješ V. i Bijelić, I. (2012). Projekti študentov v izobraževanju za trajnostni razvoj na začetku izobraževanja. U M. Duh (ur.), Ekološka in etična zavest skozi edukacijski odnos do družbe in narave, znanstvena monografja (str. 88-101). Univerza v Mariboru. Pedagoška fakulteta, Rakičan: RIS Dvorec.

Kuščević, D. (2007). Mediteransko baštinsko okružje poticaj likovnom izražavanju djece. U H. Ivon (ur.), Baština - umjetnički poticaj za likovno izražavanje djece (str. 21-27). Split: Filozofski fakultet Sveučilišta u Splitu.

Kuščević, D. (2015). Kulturna Baština - poticatelj dječjeg razvoja (likovni aspekt), Školski vjesnik - časopis za pedagoška i školska pitanja, 3(64), 479-491.

Kuščević, D., Brajčić, M. i Mišurec, Z. I. (2009). Stavovi učenika osmih razreda osnovne škole o nastavnom predmetu Likovna kultura. Školski vjesnik - časopis za pedagoška i školska pitanja, 58(2), 189-198.

Maroević, I. (2001). Koncept održivog razvoja u zaštiti kulturne baštine. Socijalna ekologija, 10(4), 235-246. https://hrcak.srce.hr/141328

Mendras, H. (2004). Europa i Europljani - Sociologija Zapadne Europe. Masmedia.

Pivac, D. (2016). Poticanje dječjeg likovnog stvaralaštva i mašte u komunikaciji s kulturnom baštinom. Školski vjesnik - časopis za pedagoška i školska pitanja, 65 (Tematski broj), 347-356. https://hrcak.srce.hr/160226

Razum, R. (2003). Motivacija vjeroučenika. A što ako je nema?. Kateheza, 25(1), 29-43. https://hrcak.srce.hr/113879

Reeves, K. i Plets, G. (2016). Cultural Heritage as a Strategy for Social Needs and Community Identity. U W. Logan, M. Nic Craith i U. Kockel (ur.), A Companion to Heritage Studies (str. 203-214). Malden: John Wiley \& Sons.

Sternberg, R. J. i Williams, W. M. (2009). Educational Psychology (2nd ed.). Pearson.

Šošić, T. M. (2014). Pojam kulturne baštine - međunarodnopravni pogled. Zbornik radova Pravnog fakulteta u Splitu, 51(4), 833-860. https://hrcak.srce.hr/129107

Vasilj, M. i Letina A. (2019). Odgoj i obrazovanje za zaštitu i očuvanje kulturne baštine. Suvremena pitanja, časopis za prosvjetu i kulturu. XIV (27), 11-28.

Vuković, M. (2011). Pogled na međuodnos baštine, kulture i identiteta. Arheološki vjesnik, 54, 97-113.

Živković, Z (1996). Potreba zaštite kulturne i prirodne baštine u ruralnome prostoru. Sociologija sela 34(3/4), 203-205. 